\title{
En utenlandsk mann med hodepine og ryggsmerter
}

\author{
En mann med afrikansk opprinnelse ble innlagt med hodepine og rygg- \\ smerter. MR-undersøkelse viste et overraskende funn. Importsykdom- \\ mer må ikke glemmes, selv hos personer som har vært lenge i Norge.
}

En mann i 40-årene fra et afrikansk land ble innlagt i medisinsk avdeling på et norsk lokalsykehus med hodepine og ryggsmerter. Han hadde vært i Europa i mange år uten å besøke hjemlandet. Tidligere hadde han hatt malaria og iridosyklitt, men ellers vært stort sett frisk. I fire år før den aktuelle innleggelsen hadde han imidlertid vært plaget av høyresidige ryggsmerter uten at det hadde gjort ham arbeidsufør. En CT-undersøkelse av lumbosakralcolumna fra den gang viste intet patologisk. Én måned før innleggelsen var det tatt MR-bilder av høyre ankel på grunn av smerter, men undersøkelsen var normal.

Ved sykehusinnleggelsen klaget han over global hodepine av seks dagers varighet. Videre bemerket han noe nedsatt synsevne og smerter ved sterk lyseksponering. Han følte seg svak i all muskulatur og hadde vondt i hele kroppen. Korsryggsmertene var blitt verre. I fire dager hadde han hatt dysuri og problemer med å late vannet. Før overflytting til sykehuset var han blitt kateterisert for $500 \mathrm{ml}$ urin på legevakten. Urinstiks var negativ.

Ved innleggelse var pasienten afebril og hadde normal orienterende nevrologisk undersøkelse. Alle rutineblodprøver med tanke på hematologi, infeksjon, nyrefunksjon og leverprøver var normale. Dagen etter hadde han fortsatt hodepine og vondt i hele kroppen. Han hadde problemer med å løfte høyre lår ved gange, men gikk ellers greit. Vi oppfattet hodepinen som pasientens hovedproblem.

Mannen snakket bra norsk, men $i$ ettertid ser vi at kommunikasjonen kunne vært bedre. Både pasienten og legene fokuserte på den nytilkomne hodepinen, og andre symptomer ble oppfattet som sekundære til denne. Pasienten hadde normale reflekser $i$ underekstremitetene, og plantarrefleksen var nedadvendt. Vi vurderte det slik at det ikke forelå noen tverrsnittlesjon, og vannlatingsproblemet ble oppfattet som smertebetinget. Han ble henvist til MR caput som ble beskrevet som normal. CT-undersøkelse var ikke tilgjengelig på det aktuelle tidspunktet.

Samme kveld ble pasienten vurdert på nytt av en annen lege på vakt. Han rekvirerte MR-undersøkelse av LS-columna på grunn av fortsatt urinretensjon og ryggsmerter.

MR-bilder av columna viste en patologisk intramedullær lesjon i nivå Th10/Th12 (fig 1a, b). I distale medulla fant man en $6 \mathrm{~cm}$ lang, spindelformet oppdriving som strakte seg til konus. Lesjonen hadde et inhomogent signal, høyere enn medulla på T2. Etter kontrast var det flekkvis, inhomogen kontrastoppladning. Medulla var såpass oppdreven at den fylte det meste av spinalkanalen.

Funnet var ikke typisk for solid tumor, transvers myelitt eller demyeliniserende sykdom, selv om det ikke kunne utelukkes. Ut fra bildefunn og klinisk undersøkelse antok man at infeksiøs årsak var en høyst aktuell differensialdiagnose, og beskrivende radiolog bemerket at schistosomiasis kunne ha et svært likt utseende. Tuberkulose var mindre sannsynlig på grunn av lokalisasjon og utseende av lesjonen og at isolert affeksjon av medulla er svært sjeldent.

På grunn av mistanke om schistosomiasis i spinalkanalen ble pasienten overført til nærmedisinsk og nevrokirurgisk kompetanse. Det ble ikke funnet indikasjon for kirurgisk intervensjon. Pasienten ble spinalpunktert med funn av 415 leukocytter i spinalvæsken (ref $<5 / \mathrm{mm} 3)$. Sp-protein var forhøyet til 624 (ref. $100-500 \mathrm{mg} / \mathrm{l}$ ), sp-albumin 372 (ref. $100-300 \mathrm{mg} / \mathrm{l}$ ), sp-glukose $4,1 \mathrm{mmol} / \mathrm{l}$ (ref. avhengig av blodsukker). Immunfenotyping av spinalvæsken ga ikke holdepunkter for lymfom.

Resultatet av spinalvæskeundersøkelsene med høye verdier for celletall og protein kombinert med MR-funnet, tydet på en inflammatorisk tilstand i sentralnervesystemet. Det ble gjort mikroskopi av urin og feces uten funn av parasitter. Dyrking av mykobakterier i spinalkanalen var negativ. Videre var det negative prøvesvar for Mycobacterium tuberculosis complex-DNA, S-TB IGRA Quantiferon, hepatitt B og C og Serum Cysticercus Western blot-antistoff (prøve sendt til Basel).

Prøver for schistosomiasis sendt til Folkhälsomyndigheten i Stockholm viste serum meste universitetssykehus med infeksjons-

\section{Per Kristian Skorpen}

perkrskorpen@gmail.com

Medisinsk avdeling

Nordlandssykehuset Vesterålen

Hanne Thoresen

Røntgenavdelingen

Nordlandssykehuset Bodø

Engelsk oversettelse på www.tidsskriftet.no 

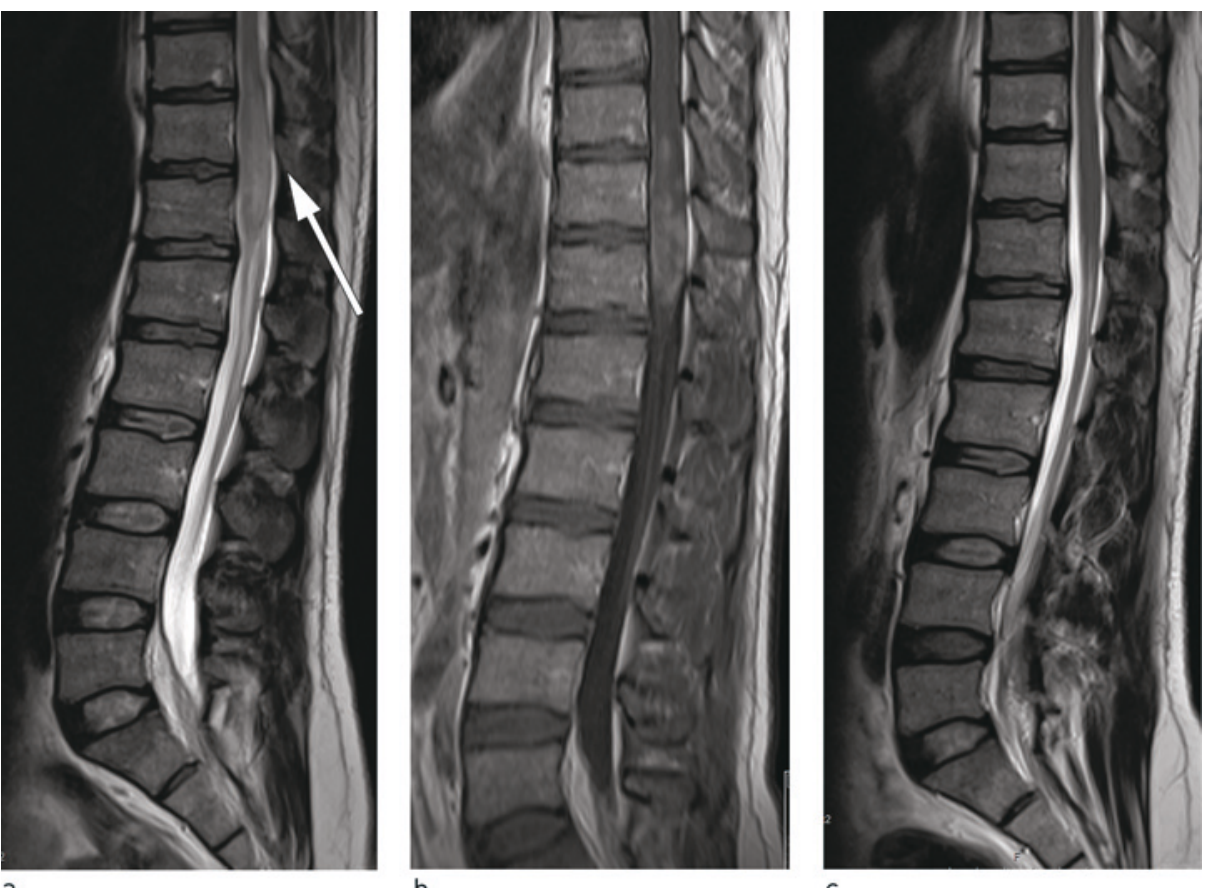

a

Etter 1-3 måneder er en voksen ikte utviklet. En hann og hunn danner et par og beveger seg til artens foretrukne endestasjon (fig 2). For Schistosoma mansoni og Schistosoma japonicum er det venene i nedre mesenteria-gebetet og colon, mens Schistosoma haematiobium finner veien til vener rundt urinblæren. Iktene kan imidlertid også bevege seg til andre organer.

Den vanligste lokalisasjonen for ektopiske ikter er sentralnervesystemet, i perivertebralt venøst pleksus eller kortikale cerebrale vener. Nevrologiske komplikasjoner kan forårsakes av eggdeponering i sentralnervesystemet. Disse fører til en cellemediert periokulær granulomatøs reaksjon. Masseeffekten av titusener av egg og de store granulomene i hjernen eller ryggmargen forklarer symptomer som økt intrakranialt trykk, myelopati, radikulopati og påfølgende sekveler. Myelopati i lumbosakralregionen er den vanligste komplikasjonen til S. mansoni og S. haematobium, men akutt encefalitt i cortex, subkortikal hvit substans, basalganglier eller capsula interna er typisk for $S$. japonicum $(2,3)$.

Det finnes mange rapporterte tilfeller av nevrologiske komplikasjoner i kasuistikker med få pasienter. I de fleste omtaler man pasienter fra endemiske områder, men det er også rapportert om en turist som etter ett bad i ferskvann under reise i Vest-Afrika utviklet symptomer fire år senere (4).

Nevroschistosomiasis er en følge av schistosomapåvirkningen av sentralnervesystemet og krever rask behandling ved symptomer. I flere kasuistikker er det rapportert om komplett remisjon av symptomer etter behandling (5-7). Det er tre hovedformer av tilstanden. Akutt schistosomal encefalopati er en tilstand med ukjent direkte årsak. Hodepine, endret sensorium, kramper, ataksi og cerebellare symptomer ses oftest (2).

Granulomatøs reaksjon i hjernevev kan gi en pseudotumor som fører til økt intrakranialt trykk. Hodepine, synsforstyrrelser, kramper og endret mental status er hovedsymptomer.

Tilsvarende reaksjon i ryggmargen er den tidligst beskrevne og best kjente formen av nevroschistosomiasis. Pasientene har ofte ingen andre symptomer. Også i disse tilfellene kan symptomene variere mye. Ryggsmerter er ofte det første symptomet med utstrålende smerter i underekstremitetene. Andre kan igjen debutere med svakhet i underekstremitetsmuskulatur, tarm og urinblæredysfunksjon, parestesier, impotens hos menn og refleksendringer i underekstremitetene (2).

Direkte diagnostikk er den eneste måten som sikkert kan bekrefte pågående schistosomiasisinfeksjon. Målet er å finne levende egg. De beskrevne schistosomaartene har ulike egg. Der schistosomiasis er utbredt, 


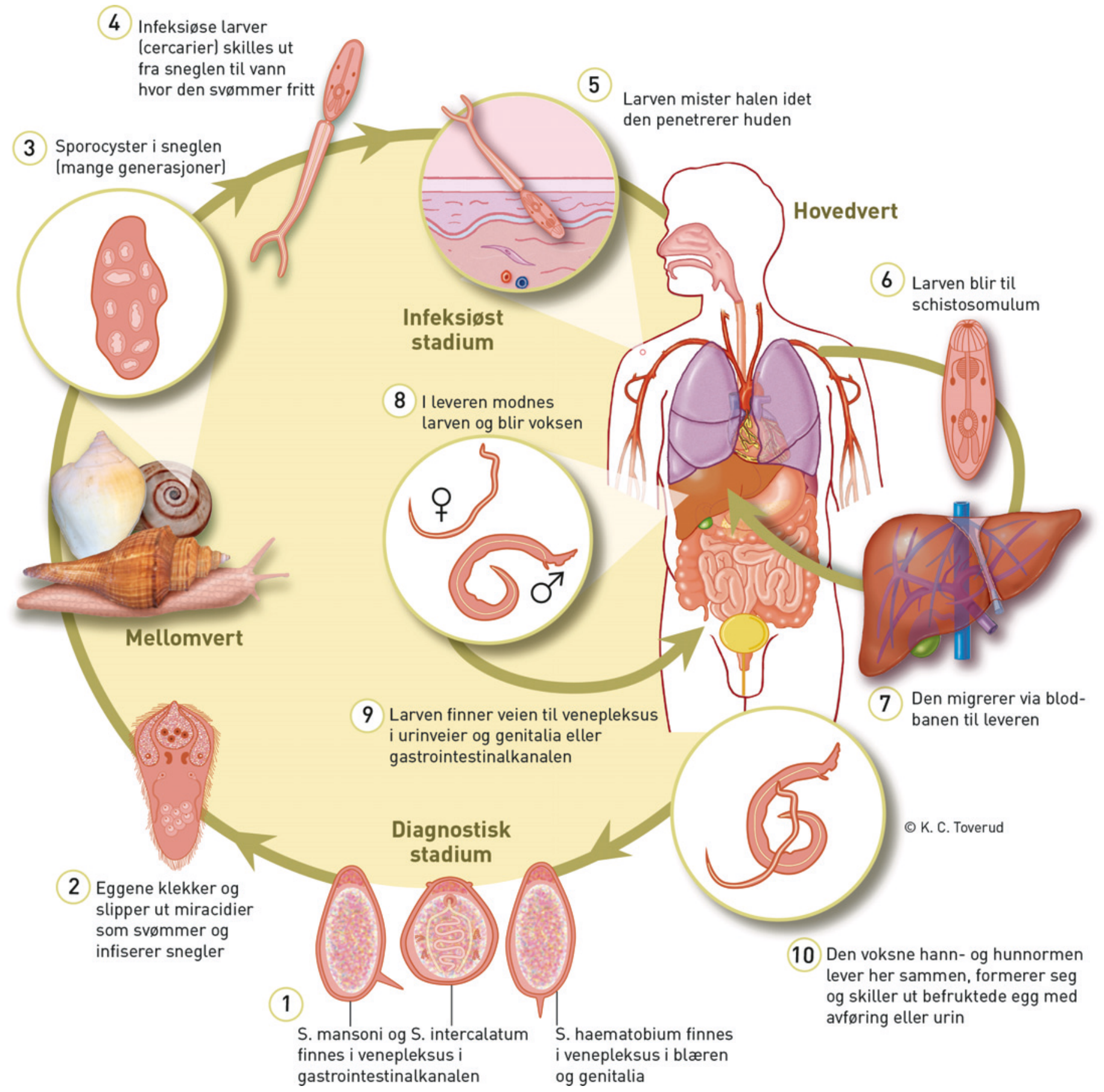

Figur 2 Livssyklusen til schistosomaparasitten

gjøres urinmikroskopi av vanlig og filtrert urin. Direkte mikroskopi av avføring er ikke en god nok sensitiv metode, men sensitiviteten kan økes ved spesielle konsentrasjonsteknikker. Funn av egg i vevsprøve kan også bekrefte diagnosen (1).

Det finnes en rekke immunologiske tester som påviser sirkulerende antischistosomale antistoffer. De sier imidlertid ikke noe om graden av infeksjon og skiller heller ikke mellom tidligere og aktuell infeksjon og er ikke artsspesifikke. De er ikke tilgjengelige for de fleste aktuelle pasientene $\mathrm{i}$ land med størst sykdomsbyrde, på grunn av pris og mangel på teknologi. Heller ikke i Norge utføres disse testene, vi sender prøver til laboratorium i Sverige. Der tester Folkhälsomyndigheten med immunofluorescens mot tarmantigen (Gut Associated Antigen, GAA) og somatisk antigen (SA). Hvis minst én av disse to er positive, testes det også mot eggantigen (soluble egg antigen, SEA) med en ELISA-metode. Tarmantigen kommer fra parasittens tarm og gulpes opp av ikten etter at den har fordøyd et blodmåltid. Det er typisk den testen som først blir positiv etter smitte, og den kan bli positiv selv før egg kan påvises i urin eller feces. Eggantigen blir som navnet angir først positiv når eggproduksjonen har kommet i gang. Somatisk antigen er et kroppslig antigen fra selve ikten og ses typisk ved kroniske infeksjoner der noen ikter har begynt å dø eller etter 
behandling (overlege Tore Lier, personlig meddelelse).

Vurdering av schistosomiasisinfeksjon i hepatospleniske og urogenitale organer kan gjøres ved bruk av ultralyd, CT- og MRundersøkelser. Ultralyd kan gjøres på sengepost og i felten og krever betydelig mindre økonomiske investeringer enn de andre modalitetene (8). CT-undersøkelse er spesielt bra for å vise forkalkninger i urinveiene, noe som er typisk for urogenital schistosomiasis (9). For ektopisk form med cerebral affeksjon eller myeloradikulopati er MR-undersøkelse beste metode. Blant befolkningsgruppene som er mest rammet, er imidlertid denne modaliteten sjelden tilgjengelig. Ved nevroschistosomiasis er distale medulla conus hyppigst affisert. På T2-sekvensen ser man heterogene høysignalforandringer og oppdrivinger av medulla, gjerne over flere segmenter. Det kan være både nodulær kontrastoppladning i medulla og perifer oppladning i leptomeningene på grunn av egg med granulomadanning begge steder. I en del tilfeller er det også affeksjon av nerverøtter og cauda equina (10-12).

Behandlingen retter seg i hovedsak mot eliminering av iktene. Videre kan behandling av de immunpatologiske komplikasjonene forårsaket av egg være aktuelt.

Praziquantel i én enkelt dose på $40 \mathrm{mg} / \mathrm{kg}$ er nok for alle schistosomaartene. Det er ikke rapportert alvorlige bivirkninger av medikamentet

Ved behandling av nevroschistosomiasis kan praziquantelbehandlingen føre til forverring av den immunologiske responsen. Behandling med steroider anbefales derfor for ikteelimineringen.

Vår pasient hadde vært minst 11 år i land der schistosomiasis ikke forekommer da han ble innlagt hos oss. At iktene kan leve mange år i menneskekroppen tydeliggjør betydnin- gen av ikke å glemme importsykdommer selv hos personer som har vært lenge i Norge. Det er rapportert om myelopati på grunn av schistosomiasis hos en pasient som ikke hadde vært eksponert for infisert vann på 22 år (13).

Myeloradikulopati forårsaket av schistosomiasis er en alvorlig og lite påaktet komplikasjon (6). Prevalensen av denne tilstanden i sentre i Brasil og Afrika, som arbeider med ikke traumatisk myelopati, er angitt til mellom $1-5 \%(2,14)$.

Undersøkelser av spinalvæsken viser økt proteinkonsentrasjon og antall mononuklære celler hos $90 \%$ av pasientene med slik myeloradikulopati (14). Det var også tilfelle hos vår pasient. MR-diagnostikk har vist seg spesielt verdifullt for denne pasientgruppen og førte også til rett diagnose i vårt tilfelle.

Ved etterundersøkelse ett år etter behandling var MR-funnene i spinalkanalen gått helt tilbake. Det viser at behandling selv lenge etter infeksjonstidspunkt har effekt. Denne observasjonen er viktig fordi svært få personer med nevroschistosomiasis blir etterundersøkt med MR-undersøkelse.

Pasienten har gitt samtykke til at artikkelen blir publisert.

\section{Per Kristian Skorpen (f. 1953)}

er spesialist $\mathrm{i}$ indremedisin og overlege ved Nordlandssykehuset, Vesterålen.

Forfatter har fylt ut ICMJE-skjemaet og oppgir ingen interessekonflikter.

\section{Hanne Thoresen ( f. 1972)}

er spesialist i radiologi og radiolog ved Diagnostisk klinikk, Nordlandssykehuset Bodø. Forfatter har fylt ut ICMJE-skjemaet og oppgir ingen interessekonflikter.
Litteratur

1. Colley DG, Bustinduy AL, Secor WE et al. Human schistosomiasis. Lancet 2014: 383: 2253-64.

2. Ferrari TCA, Moreira PR. Neuroschistosomiasis: clinical symptoms and pathogenesis. Lancet Neurol 2011; 10: 853-64.

3. Ross AG, McManus DP. Farrar J et al. Neuroschistosomiasis. J Neurol 2012; 259: 22-32.

4. Rose MF, Zimmerman EE, Hsu L et al. Atypical presentation of cerebral schistosomiasis four years after exposure to Schistosoma mansoni. Epilepsy Behav Case Rep 2014: 2: 80-5.

5. Lobo PP, Coelho M, Geraldes R et al. Myeloradiculopathy associated to Schistosoma mansoni. BMJ Case Rep 2011; 2011: bcr1220103631.

6. Algahtani HA, Aldarmahi AA, Al-Rabia MW et al. Acute paraplegia caused by Schistosoma mansoni. Neurosciences (Riyadh) 2014; 19: 47-51.

7. Badr HI, Shaker AA, Mansour MA et al. Schistosomal myeloradiculopathy due to Schistosoma mansoni: Report on 17 cases from an endemic area. Ann Indian Acad Neurol 2011; 14: 107-10.

8. Olveda DU, Olveda RM, Lam AK et al. Utility of diagnostic imaging and the diagnosis and management of schistosomiasis. Clin Microbiol 2014: 3: 142

9. Shebel HM, Elsayes KM, Abou El Atta HM et al. Genitourinary schistosomiasis: life cycle and radiologic-pathologic findings. Radiographics 2012; 32: 1031-46.

10. Szekeres C, Galletout P, Jaureguiberry S et al. Neurological presentation of schistosomiasis. Lancet 2013; 381: 1788

11. Saleem S, Belal Al, El-Ghandour NM. Spinal cord schistosomiasis: MR imaging appearance with surgical and pathologic correlation. AJNR Am J Neuroradiol 2005; 26: 1646-54.

12. da Silveira Carvalho GB, Sandim GB, Tobarau Tibana LA et al. Magnetic resonance imaging in the differential diagnosis of infectious and inflammatory conus medullaris lesions. Radiol Bras 2013; 46: 51-5.

13. Macdonald CA, Jardine DL, Hurrell MA et al. The worm that turned. Trans R Soc Trop Med Hyg 2009: 103: 1065-7.

14. Lambertucci JR, Silva LC, do Amaral RS. Guidelines for the diagnosis and treatment of schistosomal myeloradiculopathy. Rev Soc Bras Med Trop 2007: 40: 574-81.

Mottatt 26.6. 2016, første revisjon innsendt 25.11. 2016, godkjent 1.2. 2017. Redaktør: Liv-Ellen Vangsnes. 